\title{
ハイブッシュブルーベリーにおける夏秋季開花性の品種間差
}

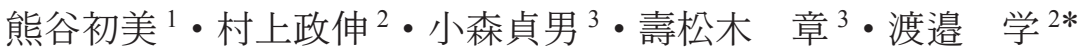 \\ 1 岩手大学大学院連合農学研究科 $020-8550$ 盛岡市上田 \\ 2 岩手大学農学部附属寒冷フィールドサイエンス教育研究センター 020-0611 滝沢市巣子 \\ 3 岩手大学農学部 020-8550 盛岡市上田
}

\section{The Differences of Summer-autumn Flowering Among Highbush Blueberry Cultivars}

\author{
Hatsumi Kumagai ${ }^{1}$, Masanobu Murakami ${ }^{2}$, Sadao Komori ${ }^{3}$, \\ Akira Suzuki ${ }^{3}$ and Manabu Watanabe ${ }^{2 *}$ \\ ${ }^{1}$ The United Graduate School of Agricultural Sciences, Iwate University, Ueda, Morioka, Iwate 020-8550 \\ ${ }^{2}$ Field Science Center, Faculty of Agriculture, Iwate University, Sugo, Takizawa, Iwate 020-0611 \\ ${ }^{3}$ Faculty of Agriculture, Iwate University, Ueda, Morioka, Iwate 020-8550
}

\begin{abstract}
To apply summer-autumn flowering of highbush blueberry to two-season harvesting and autumn harvesting, we investigated the timing and degree of flowering in summer-autumn for 78 highbush blueberry cultivars. 'Bluetta', 'Puru', and 'Bluecrisp' flowered readily during the summer-autumn. Moreover, summer-autumn flowering was observed at the tip of shoots from midJuly to mid-November. The shoot lengths were around 70-100 cm. One-year-old branches that flower in summer-autumn differed among cultivars, for example, 'Bluetta', 'Patriot', and 'Spartan' flower from shoots and suckers, but 'Bluecrisp' flowers from shoots only. Inflorescences that flowered in the summer-autumn showed a form unlike that of inflorescences that flower in spring. These did not form flower fruit clusters, and there were individual florets located in each leaf axil of the shoot. Moreover, the number of florets per shoot was 3.9-4.8. The day temperature was slightly lower, the duration of sun light was shorter, and summer-autumn flowerings were more numerous in July 2013 than in 2014-2015. Moreover, temperatures in September and October in 2013 were higher. The results suggest that flowering during the summer-autumn is related to climatic conditions.
\end{abstract}

Key Words : floral differentiation, two-season harvesting, unseasonable blooming, Vaccinium corymbosum L.

キーワード：不時開花，花芽分化，二季採り，Vaccinium corymbosum L.

\begin{abstract}
緒言
我が国のブルーベリー生産は1951年に米国からハイ ブッシュブルーベリーが導入されて以来，日本各地に広ま り, 特に 1990 年代後半以降, 栽培面積および収穫量とも に増加した. 農林水産省が発表した特産果樹生産動態調査 によると, 岩手県のブルーベリ一生産は 2003 年の栽培面 積 30.6 ha, 出荷量 $56.9 \mathrm{t}$ から 2011 年には 53.0 ha, $93.2 \mathrm{t}$ で増加している. しかし, 国産生果の供給時期は 6 月上 旬〜9月上旬に限られて拈り，10月〜翌年 5 月までの才 フシーズンは輸入果実に頼っている（堀内ら，2013）。よっ て, 現在の栽培体系では, 年間を通して国産の新鮮な生果 を供給することはできない. 2013 年から 2014 年にかけて の東京都中央卸売市場でのブルーベリ一生果の取扱量と平
\end{abstract}

2017 年 3 月 14 日 受付. 2017 年 8 月 3 日 受理.

本報告の一部は園芸学会平成 25 年春季大会および平成 26 年度 春季大会で発表した.

* Corresponding author. E-mail: mwata@iwate-u.ac.jp
均価格によると，ブルーベリ一生果の主な出荷時期は5 月〜 8 月で, 出始めとなる 5 月の平均果実価格は $1 \mathrm{~kg}$ 当た り 2,813 円であるが，旬を迎光取扱量が増加する 7 月，8月 の平均価格は $1,380 \sim 1,649$ 円となり，価格は 5 月よりも 1,200 ～1,500 円下がる. 寒冷な気象条件にある北東北では 7 月, 8 月の出荷がメインとなるため, 平均価格が最も低 い時期の出荷となり，他県よりも時期的に優位な販売の展 開は難しい。しかし，9月には取扱量が減少し，10月には 平均価格が上昇するため, 岩手県でもより収穫時期を遅ら せることで, 高単価の時期に出荷可能になると考えられる.

ブルーベリーの新梢は，4月上旬頃に葉芽が発芽し，6 月下旬〜 7 月上旬まで伸長が続く。その後，停止した新梢 の先端の成長点がブラックチップと呼ばれる黒い小片に変 化する. このブラックチップは 2 週間流どして落下し，そ の後，新梢では花芽分化もしくは二次伸長，三次伸長が起 こる. この際，形成された花芽は，翌年の春に開花する (玉田, 1998).

一方, 堀内ら（2013）は, ポット栽培したブルーベリー 樹を休眠前である 11 月にビニルハウスへ入庫させ，高温・ 
長日処理を行い, ‘Emerald’ および ‘Sharpblue’ では, 開 花, 結実が誘導され翌年 7 月まで収穫が続いたことを報告 している.さらに, Thandaら（2014）は，自然光扎よび人 工光型栽培室で栽培した 'Blueray' および ‘Misty' の果実 サイズ, 果実品質和よび果皮の含有アントシアニン量を比 較し, 人工光型栽培室で栽培した場合, 自然光に比べ糖度 扣よびアントシアニン量が高く, 滴定酸度が低下したこと を報告している. 現在では, この人工光型植物工場を利用 することで，ブルーベリ一生果の周年供給が可能になって いる(荻原，2013）。しかし，これらの方法では八ウスの 設置や冷暖房，人工光源が必要となるためコストがかか り，また，生産規模に执いて制約がある。

岩手大学農学部附属寒冷フィールドサイエンス教育研究 センタ一滝沢農場に植栽されているブルーベリーでは, 一 部の品種に夏秋季に開花, 結実する現象がみられる. この よらな夏秋季の開花执よび結実の場合は, 春から伸長した 当年枝の先端に開花, 結実する（第 1 図 A, B, C, ). 同様 の現象は，オーストラリアのニューサウスウェールズ州で 植栽されている 'Sharpblue’ でもみられているが, 発生の 機構は不明である（Wright, 1993）。果樹では強風や病害虫 によって夏から秋にかけて激しい落葉が起きた際, 不時開 花が起こる場合がある（黒田，2002）。この現象を応用し， 熱帯高地ではリンゴの二期作が行われている. また, 丸尾 ら（1999）は, 剪定, 植物ホルモン処理および長日処理を 用いて，ブドウ ‘藤稔’ の開花を誘導することで，二期作
技術確立を試みた。 このように不時開花は作期拡大に利用 できる場合がある，従って，ブルーベリーでも夏秋季開花 の発生を調節することができれば，夏秋季採りまたは春季 と夏秋季の二季採りができる可能性がある。しかし，夏秋 季開花の発生品種拉よび発生様式は不明である。そこで, 本研究では，夏秋季開花を夏秋季採りまたは二季採りに応 用することを目的に，ハイブッシュブルーベリー 78 品種 について，夏秋季開花の発生時期およびその程度などを 3 年間調査した.

\section{材料および方法}

岩手大学農学部附属寒冷フィールドサイエンス教育研究 センター滝沢農場に植栽されているハーフハイハイブッ シュブルーベリー種（以下，ハーフハイハイブッシュ種） 8 品種, 計 36 樹, ノーザンハイブッシュブルーベリー種 (以下，ノーザンハイブッシュ種） 47 品種, 計 356 樹, サ ザンハイブッシュブルーベリー種（以下，サザンハイブッ シュ種） 23 品種，計 68 樹（第 1 表）について以下の調査 を行った。なお，供試樹の樹齢は品種により異なり，調査 開始の 2013 年時点で 7〜 31 年生であった.

新梢抏よび小花ごとに夏秋季の開花時期と開花した新梢 の種類および長さを調査した。新梢は前年枝以前の枝から 発生したものをシュート, 地際から発生したものをサッ カーと定義して，分類した。夏秋季開花は，一次伸長枝た けではなく, 二次, 三次伸長した新梢の先端に発生するこ

第 1 表 夏秋季の開花調査に供試した品種

\begin{tabular}{|c|c|c|c|c|c|c|c|c|c|c|c|c|}
\hline 種 & 品種名 & $\begin{array}{l}\text { 樹数 } \\
\text { (本) }\end{array}$ & $\begin{array}{l}\text { 樹齢 }^{z} \\
\text { (年) }\end{array}$ & 品種名 & $\begin{array}{l}\text { 樹数 } \\
\text { (本) }\end{array}$ & $\begin{array}{l}\text { 樹齢 } \\
\text { (年) }\end{array}$ & 品種名 & $\begin{array}{l}\text { 樹数 } \\
\text { (本) }\end{array}$ & $\begin{array}{l}\text { 樹齢 } \\
\text { (年) }\end{array}$ & 品種名 & $\begin{array}{l}\text { 樹数 } \\
\text { (本) }\end{array}$ & $\begin{array}{l}\text { 樹齢 } \\
\text { (年) }\end{array}$ \\
\hline \multirow{2}{*}{$\begin{array}{l}\text { ハーフハイ } \\
\text { ハイブッシュ種 }\end{array}$} & Chippewa & 3 & 7 & Friendship & 3 & 7 & Northblue & 1 & 31 & Northcountry & 1 & 31 \\
\hline & Northland & 19 & 31 & Northsky & 1 & 31 & Polaris & 5 & 7 & Tophat & 3 & 7 \\
\hline \multirow{12}{*}{$\begin{array}{l}\text { ノーザン } \\
\text { ハイブッシュ種 }\end{array}$} & Berkeley & 26 & 31 & Bluechip & 15 & 19 & Bluecrop & 13 & 31 & Bluegold & 3 & 7 \\
\hline & Bluehaven & 12 & 31 & Bluejay & 14 & 31 & Blueray & 9 & 31 & Bluetta & 19 & 31 \\
\hline & Bonus & 2 & 7 & Brigitta & 10 & 14 & Cara's choice & 3 & 7 & Charolineblue & 9 & 16 \\
\hline & Chandler & 2 & 7 & Collins & 8 & 31 & Concord & 1 & 31 & Coville & 4 & 31 \\
\hline & Croatan & 3 & 7 & Darrow & 5 & 31 & Denise & 4 & 16 & Dixi & 7 & 31 \\
\hline & Duke & 9 & 14 & Earliblue & 6 & 31 & Echota & 2 & 7 & Elizabeth & 3 & 7 \\
\hline & Elliott & 1 & 31 & Harrison & 11 & 14 & Herbert & 14 & 31 & Jersey & 27 & 31 \\
\hline & June & 2 & 31 & Lateblue & 4 & 31 & Legacy & 3 & 7 & Meader & 8 & 31 \\
\hline & Nelson & 8 & 14 & Nui & 5 & 19 & Patriot & 20 & 19 & Pemberton & 5 & 31 \\
\hline & Puru & 5 & 19 & Rancocas & 1 & 31 & Reka & 5 & 19 & Rubel & 3 & 31 \\
\hline & Sierra & 12 & 19 & Spartan & 17 & 19 & Stanley & 2 & 31 & Sunrise & 3 & 7 \\
\hline & Toro & 7 & 14 & Weymouth & 1 & 31 & はやばや星 & 3 & 7 & & & \\
\hline \multirow{6}{*}{$\begin{array}{l}\text { サザン } \\
\text { ハイブッシュ種 }\end{array}$} & Avonblue & 2 & 7 & Bladen & 3 & 7 & Bluecrisp & 3 & 16 & BlueRidge & 3 & 7 \\
\hline & CapeFear & 1 & 16 & Cooper & 3 & 7 & Duplin & 3 & 7 & Emerald & 3 & 7 \\
\hline & Flodablue & 3 & 16 & Georgiagem & 2 & 16 & Jewel & 2 & 16 & Magnolia & 3 & 7 \\
\hline & Millennia & 3 & 7 & Misty & 2 & 16 & O’Neal & 4 & 16 & Ozarkblue & 2 & 7 \\
\hline & PearlRiver & 3 & 16 & Reveille & 5 & 16 & Sapphire & 5 & 16 & Sharpblue & 5 & 16 \\
\hline & Southmoon & 2 & 16 & Star & 3 & 16 & Summit & 3 & 7 & & & \\
\hline
\end{tabular}

\footnotetext{
${ }^{\mathrm{z}} 2013$ 年の樹齢を示した
} 
ともある。そこで，2014年拉よび 2015 年に夏秋季開花し た新梢を，伸長次数別に分類した．2013 年には7月下旬〜 11 月下旬に，第 1 表に示したブルーベリ一樹について， 3〜4 日扮きに観察した. 夏秋季開花の発生した新梢に対 しナンバリングしてラベルをつけ，新梢の長さを計測し， 小花ごとに開花日を記録した。2014 年には 7 月中旬 11 月下旬に次のように調查した。 2013 年に, 夏秋季開花の 発生頻度が比較的高かった 'Bluetta', 'Patriot', 'Puru', 'Bluecrisp’ および 'Spartan’ の5 品種のみ 3〜4 日拉きに, 他品種は約 1 か月ごとに調査した。 その他の調查方法は 2013 年と同様である。また，2015 年には，11月上旬に夏 秋季開花した新梢数とその新梢の長さおよび伸長次数を計 測した．2016年には，7月中旬～11月下旬に夏秋季開花 した新梢数打よび小花数を計測した。

\section{結果}

\section{1. 夏秋季開花の花序の形態}

夏秋季の開花では，花房を形成せず，当年に伸長した新 梢の先端部の各葉腋に 1 つずつ小花をつけた（第 1 図 A, B, C). 'Bluetta', 'Patriot', 'Puru', 'Spartan' 拈よび 'Bluecrisp’では，その小花数は $3.9 \sim 4.8$ 個であった（第 2 表）.

\section{2. 夏秋季開花の特性（2013 年）}

2013 年の夏秋季の開花は，27品種，全 106 樹，全新梢 数 273 本でみられた (第 3 表)。種別にみると, ハーフハ
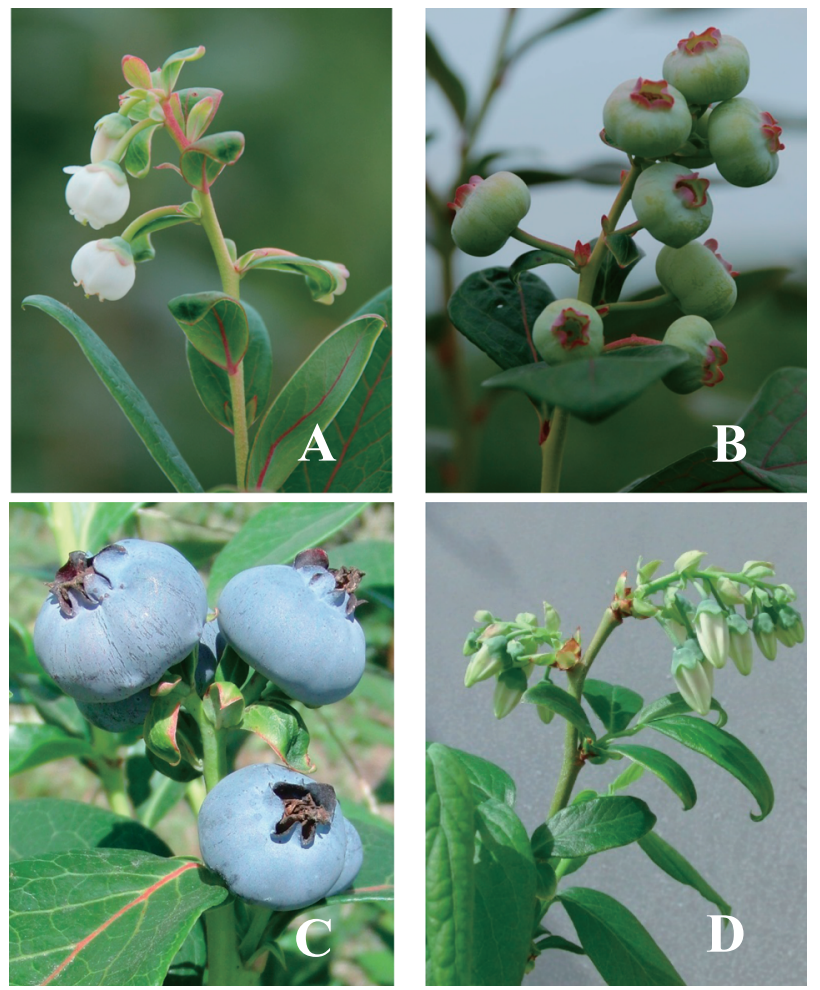

第1図 春季の開花拈よび夏秋季の開花, 結実

A : 2013 年 8 月 'Patriot' B : 2013 年 8 月 'Patriot' C : 2013 年 9 月 'Spartan’ D : 2017 年 5 月 'Spartan'
第 2 表 夏秋季開花した新梢当たりの小花数（2016年）

\begin{tabular}{lcc}
\hline \hline \multicolumn{1}{c}{ 品種 } & $\begin{array}{c}\text { 夏秋季開花した } \\
\text { 新梢数 }\end{array}$ & $\begin{array}{c}\text { 新梢当たりの小花数 } \\
\text { (小花数 } / \text { 新梢) }\end{array}$ \\
\hline Bluetta & 49 & $4.1 \pm 0.3^{\mathrm{z}}$ \\
Patriot & 27 & $4.8 \pm 0.4$ \\
Puru & 23 & $3.9 \pm 0.5$ \\
Spartan & 18 & $4.3 \pm 0.5$ \\
Bluecrisp & 10 & $4.4 \pm 1.0$ \\
\hline
\end{tabular}

$\mathrm{z}$ 平均 \pm 標準詋差

イハイブッシュ種では 4 品種，全 11 樹，ノーザン八イブッ シュ種では 19 品種，全 86 樹，サザンハイブッシュ種では 4 品種，全 9 樹でみられた。調查品種中の開花した品種の 割合は，ハーフハイハイブッシュ種は $50.0 \%$ ，ノーザン八

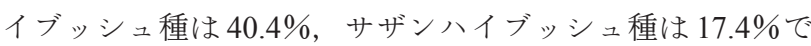
あった，夏秋季開花が発生した樹数の割合は，'Bluetta' 扔 よび 'Bluecrisp' では 100\%と高く, 次いで, 'Puru', 'Patriot' および 'Dixi’で，それ尔れ 80.0\%，78.6\%おおび 71.4\%で あった. 'Friendship', 'Polaris', 'Bluejey', 'Earliblue', 'June', 'Reka', 'Sierra', 'Spartan', 'Emerald', 'Flodablue' 㧊よび 'Star' の発生樹数の割合は $50 \sim 70 \%$ であり，その他の品 種では $50 \%$ 未満であった。 また，樹当たりの開花した新 梢数は 'Puru'で最も多く, 5.8 本であり, 次いで 'Bluetta' の 4.8 本, 'Bluecrisp' の 4.3 本, 'Patiriot'の 2.6 本の順で あった. 'Friendship', 'Bluejay', 'Earliblue', 'June', 'Reka', 'Sierra', 'Spartan', 'Flodablue' 扤よび 'Star' では1.0〜 1.8 本であり, 他の品種では, 1.0 本末満であった。

'Bluetta'，'Patriot' 拉よび ‘Spartan' ではシュート扎よび サッカーの両方で夏秋季開花が発生したが，時期が遅くな るにつれて，シュートからサッカーに移行した(第2図). 一方，'Puru' ではサッカーのみ, 'Bluecrisp’ ではシュート の久で夏秋季開花が発生した。 'Bluetta'，'Spartan’ 㸵よび 'Bluecrisp' に扮けるシュート上の夏秋季開花の発生ピー クは 8 月上中旬であったが，'Patriot'では7月下旬と他品

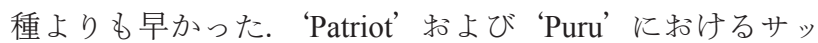
カ一上の夏秋季開花の発生ピークは9月下旬であったのに 対し, 'Spartan’ では10月中旬と遅かった。 また, 'Bluetta' ではサッカー上の夏秋季開花の発生ピークが，8月中旬と 9 月下旬 10 月の 2 時期存在した.

\section{3. 夏秋季開花の特性（2014 年）}

2014 年の夏秋季開花の発生は，19品種，全 57 樹，全新 梢数 151 本でみられた。種別にみると，ハーフハイハイ ブッシュ種で 3 品種，全 5 樹，ノーザン八イブッシュ種で 13 品種, 全 49 樹, サザンハイブッシュ種で 3 品種, 全 3 樹であった (第 3 表)。調査品種中の開花した品種の割合 は，ハーフハイハイブッシュ種が $37.5 \%$ ，ノーザン八イ

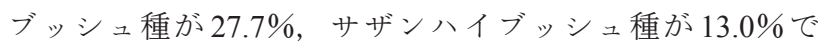
あった．夏秋季に開花した樹数の割合は，'Patriot'および ‘Dixi”が，それ攵れ 75.0\%拈よび71.4\%であり，次いで 
第 3 表 夏秋季開花した品種と開花した樹数の割合および開花した新梢数の種類

\begin{tabular}{|c|c|c|c|c|c|c|c|c|c|}
\hline \multirow{2}{*}{ 種 } & \multirow{2}{*}{ 番号 } & \multirow{2}{*}{ 品種 } & \multirow{2}{*}{$\begin{array}{l}\text { 調查 } \\
\text { 樹数 }\end{array}$} & \multicolumn{3}{|c|}{ 開花した樹数の割合（\%) } & \multicolumn{3}{|c|}{ 開花した新梢数 (本／樹) } \\
\hline & & & & 2013 年 & 2014 年 & 2015 年 & 2013 年 & 2014 年 & 2015 年 \\
\hline \multirow{4}{*}{ ハーフハイハイブッシュ } & 1 & Chippewa & 3 & 33.3 & 33.3 & 33.3 & 0.3 & 0.3 & 0.3 \\
\hline & 2 & Friendship & 3 & 66.7 & 0 & 66.7 & 1.0 & 0 & 0.7 \\
\hline & 3 & Northland & 19 & 26.3 & 5.3 & 0 & 0.6 & 0.1 & 0.2 \\
\hline & 4 & Polaris & 5 & 60.0 & 60.0 & 20.0 & 0.8 & 0.8 & 0 \\
\hline \multirow{20}{*}{ ノーザンハイブッシュ } & 5 & Bluejay & 15 & 66.7 & 13.3 & 6.7 & 1.1 & 0.1 & 0.1 \\
\hline & 6 & Bluegold & 4 & 25.0 & 25.0 & 25.0 & 0.3 & 0.3 & 0.3 \\
\hline & 7 & Bluetta & $19^{\mathrm{z}}$ & 100 & 47.4 & 68.4 & 4.8 & 1.9 & 1.3 \\
\hline & 8 & Collins & 8 & 12.5 & 0 & 0 & 0.1 & 0 & 0 \\
\hline & 9 & Coville & 4 & 25.0 & 25.0 & 0 & 0.5 & 0.3 & 0 \\
\hline & 10 & Dixi & 7 & 71.4 & 71.4 & 71.4 & 0.9 & 2.9 & 0.7 \\
\hline & 11 & Earliblue & 6 & 66.7 & 16.7 & 33.3 & 1.8 & 0.2 & 0.3 \\
\hline & 12 & Harrison & 11 & 27.3 & 0 & 9.1 & 0.5 & 0 & 0.1 \\
\hline & 13 & Herbert & 14 & 42.9 & 7.1 & 0 & 0.6 & 0.1 & 0 \\
\hline & 14 & June & 2 & 50.0 & 50.0 & 0 & 1.0 & 0.5 & 0 \\
\hline & 15 & Meader & 8 & 25.0 & 0 & 0 & 0.3 & 0 & 0 \\
\hline & 16 & Nelson & 8 & 25.0 & 12.5 & 12.5 & 0.3 & 0.4 & 0.1 \\
\hline & 17 & Nui & 5 & 20.0 & 0 & 0 & 0.4 & 0 & 0 \\
\hline & 18 & Patriot & 20 & 78.6 & 75.0 & 35.0 & 2.6 & 1.8 & 0.7 \\
\hline & 19 & Rancorcas & 1 & 0 & 0 & 100 & 0 & 0 & 2.0 \\
\hline & 20 & Puru & 5 & 80.0 & 60.0 & 60.0 & 5.8 & 2.0 & 0.8 \\
\hline & 21 & Reka & 5 & 60.0 & 0 & 0 & 1.8 & 0 & 0 \\
\hline & 22 & Rubel & 3 & 33.3 & 0 & 0 & 0.7 & 0 & 0 \\
\hline & 23 & Sierra & 12 & 66.7 & 25.0 & 16.7 & 1.4 & 0.6 & 0.3 \\
\hline & 24 & Spartan & 17 & 52.9 & 35.3 & 17.6 & 1.1 & 0.7 & 0.2 \\
\hline \multirow{4}{*}{ サザンハイブッシュ } & 25 & Bluecrisp & 3 & 100 & 33.3 & 66.7 & 4.3 & 1.7 & 3.3 \\
\hline & 26 & Emerald & 3 & 66.7 & 33.3 & 66.7 & 0.7 & 0.3 & 1.3 \\
\hline & 27 & Flodablue & 3 & 66.7 & 33.3 & 33.3 & 1.0 & 0.3 & 0.7 \\
\hline & 28 & Star & 3 & 66.7 & 0 & 33.3 & 1.0 & 0 & 0.7 \\
\hline
\end{tabular}

${ }^{z} 2013$ 年は 13 樹

‘Polalis’ 扎よび ‘Puru’が 60.0\%で，その他の品種では $50 \%$ 以下であった. また，樹当たりの開花した新梢数 は，'Dixi’ で最も多く2.9本で，次いで ‘Puru’の 2.0 本， 'Bluetta' の 1.9 本, ‘Patriot' の 1.8 本, 'Bluecrisp' の 1.7 本 の順で，他の品種では 0.8 本以下であった.

夏秋季開花した新梢は 'Spartan' および 'Bluecrisp' で はシュートでのみの発生であり, 他の 3 品種ではシュー ト扎よびサッカーであった（第3図）。'Patriot'拈よび ‘Spartan’では7月下旬がピークであった。'Bluetta’, ‘Puru’执よび ‘Bluecrisp’ に颃けるシュート上の夏秋季開 花発生の明瞭なピークは存在しなかった. 'Bluetta' にお けるサッカー上の夏秋季開花の発生は 9 月上旬にピークを 迎えた。な扣，夏秋季開花がサッカー上に発生するすべて の品種に扮いて，2013年よりもサッカ一上の発生数が激 減した。 2014 年に夏秋季開花した新梢の長さを第 4 表に 示した。 二次，三次伸長した新梢でも夏秋季開花は見られ たが，一次伸長のみの新梢より開花枝数は少なかった。
た，二次，三次伸長した新梢に括いても，シュートおよび サッカーの長さは一次伸長のみの新梢と同様に 70 $100 \mathrm{~cm}$ 程度であった。

\section{4. 夏秋季開花の特性（2015 年）}

2015 年の夏秋季開花の発生は，19品種，全 50 樹，全新 梢数 83 本でみられた，種別にみると，ハーフハイハイブッ シュ種では 3 品種, 全 4 樹, ノーザンハイブッシュ種では 12 品種, 全 40 樹, サザンハイブッシュ種では 4 品種, 全 6 樹が夏秋季に開花した（第 3 表）。調査品種中の開花した

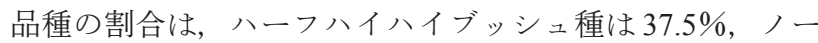
ザンハイブッシュ種は $25.5 \%$ ，サザン八イブッシュ種は 17.4\%であった. 2015 年に扣いては，過去 2 年間で開花し なかった 'Rancorcas'での開花がみられた。1樹しかない 'Rancorcas'を除いて，夏秋季に開花した樹の割合が多 かったのは 'Dixi' 抽よ゙'Bluetta'で，それぞれ71.4\% および68.4\%であった。. 次いで 'Friendship', 'Bluecrisp' 执よび ‘Emerald’ の 66.7\%, 'Puru’ の 60.0\%であり，その 

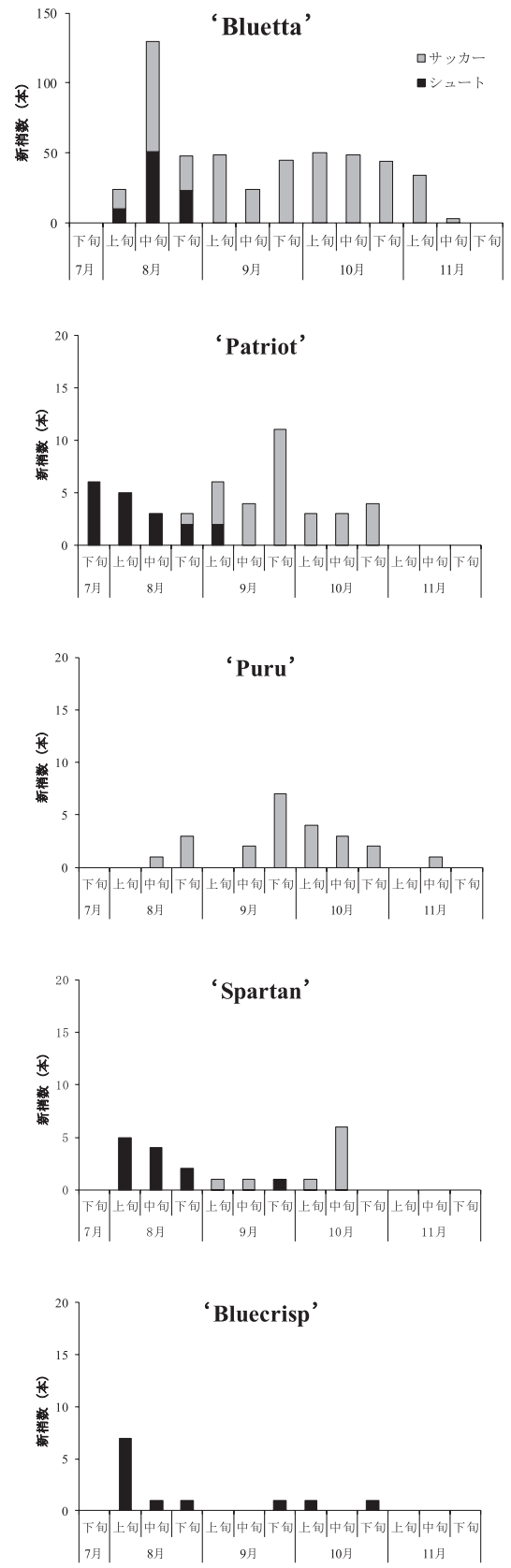

第 2 図 夏秋季開花した新梢数の推移（2013 年）

他の品種では $35 \%$ 以下であった．また，樹当たりの開花 した新梢数は 1 樹しかない ‘Rancocas'を除いて 'Bluecrisp' が3.3本と多く，次いで 'Bluetta' および ‘Emerald’の 1.3 本であり, 他の品種では 0.8 本以下であった.

夏秋季開花した新梢は 'Bluecrisp'，'Puru'特よび 'Spartan' でシュートのみであった(第4表)。'Bluetta' おo よび 'Patriot' ではシュート抢よびサッカーで夏秋季開花 した. ‘Bluecrisp’を除いた 4 品種では, 夏秋季開花した新 梢の長さはいずれも約 $60 \mathrm{~cm}$ 以上であった. しかし， 'Patriot' の二次伸長枝では, $50 \mathrm{~cm}$ 程度の新梢長であった.

5. 夏秋季開花した樹数の割合と開花した新梢数の関係 各品種に打ける 3 年間の夏秋季開花した樹数の割合打
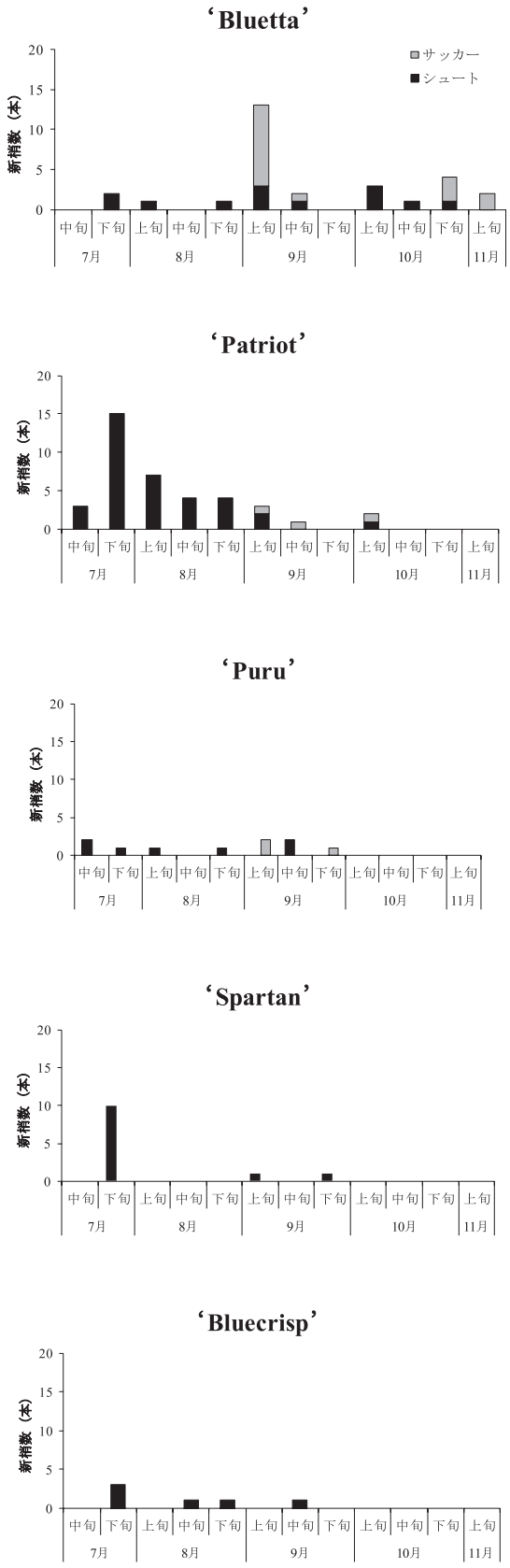

第 3 図 夏秋季開花した新梢数の推移（2014年）

よび開花した新梢数の平均值を求め, これらの関係を第 4 図に示した。'Bluetta'(第4図 7), 'Puru'（同 20）打よび 'Bluecrisp'（同 25）が，他品種よりも夏秋季開花した樹数 の割合が高く，から開花した新梢数も多かった.

\section{考察}

ブルーベリーの夏秋季開花は，いずれの種でも発生し， 夏秋季開花する品種の割合は，ハーフハイハイブッシュ 種，ノーザンハイブッシュ種，サザンハイブッシュ種の順 に高かった（第 3 表）。また， 3 年間の調査から，夏秋季 開花しやすい品種は 'Bluetta', 'Puru’ 䦽よび 'Bluecrisp' であった (第 4 図)。夏秋季開花は，7月中下旬〜 11月上 
第 4 表 夏秋季開花した新梢の長さ（2014 年, 2015 年）

\begin{tabular}{|c|c|c|c|c|c|c|c|}
\hline \multirow{2}{*}{ 年度 } & \multirow{2}{*}{ 品種 } & \multicolumn{3}{|c|}{ シュート長 (cm) } & \multicolumn{3}{|c|}{ サッカー長 (cm) } \\
\hline & & 一次伸長 & 二次伸長 & 三次伸長 & 一次伸長 & 二次伸長 & 三次伸長 \\
\hline \multirow{5}{*}{2014} & Bluetta & $93.5 \pm 29.2^{z}(6)^{y}$ & $94.0 \pm 47.3$ & $78.6 \pm 33.9(2)$ & $97.6 \pm 14.7(24)$ & $73.0 \pm 0(2)$ & - \\
\hline & Patriot & $72.6 \pm 21.9 \quad(23)$ & $69.4 \pm 49.5(5)$ & $-{ }^{\mathrm{x}}$ & $95.6 \pm 3.15(3)$ & - & - \\
\hline & Puru & $72.7 \pm 24.9$ & $91.9 \pm 46.7(2)$ & $89.3(1)$ & $80.1 \pm 14.1$ & - & - \\
\hline & Spartan & $71.1 \pm 17.7(11)^{\mathrm{w}}$ & - & - & - & - & - \\
\hline & Bluecrisp & $65.0 \pm 17.4 \quad(3)^{\mathrm{w}}$ & $75.3 \pm 51.7(2)^{\mathrm{w}}$ & - & - & - & - \\
\hline \multirow{5}{*}{2015} & Bluetta & $68.7 \pm 21.4$ & $75.4 \pm 29.8$ & - & $61.9 \pm 10.8(16)$ & $150.4(1)$ & - \\
\hline & Patriot & $72.1 \pm 7.0$ & $48.4 \pm 5.1$ & - & $118.8 \pm 21.8$ & $70.0(1)$ & - \\
\hline & Puru & $59.8 \pm 3.2$ & - & - & - & - & - \\
\hline & Spartan & $88.1 \pm 22.2$ & - & - & - & - & - \\
\hline & Bluecrisp & $48.0 \pm 8.9(10)^{\mathrm{w}}$ & - & $26.3(1)^{\mathrm{w}}$ & - & - & - \\
\hline
\end{tabular}

$\mathrm{z}$ 平均 \pm 標準偏差

y カッコ内は, 新梢長を計測した新梢数を示す

x_は，夏秋季開花した新梢がなかったことを示す

w夏秋季開花した新梢のらち一部新梢長を計測していないものがある

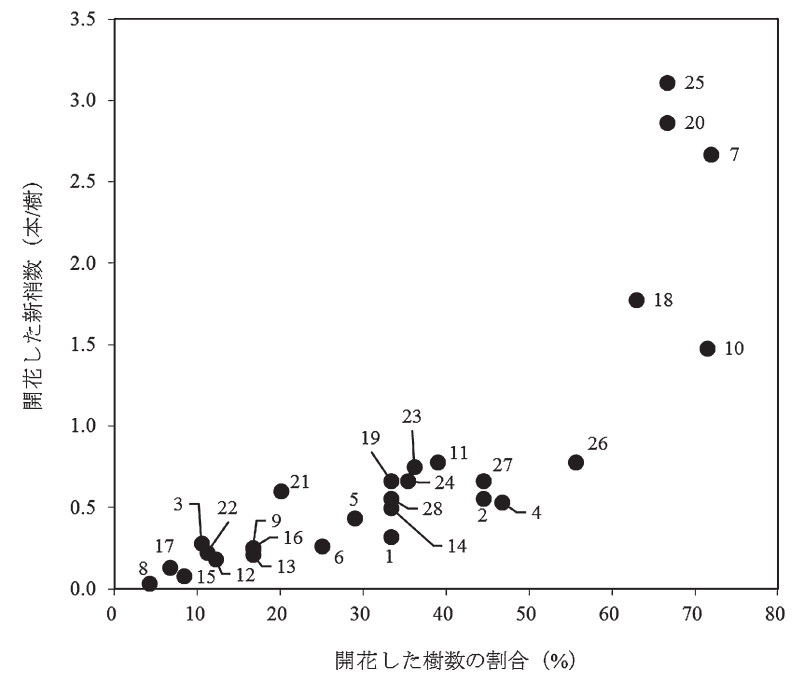

第 4 図 夏秋季に開花した樹数の割合と開花した新梢数の関係 図中の数字は第 3 表の番号と対応している

中旬に (第 2 図, 第 3 図), $70 \sim 100 \mathrm{~cm}$ 程度の比較的長い 新梢の先端で発生した（第4 表)。2013 年，2014年を通し て, 'Bluetta', 'Patriot’ および 'Spartan’ では, シュート抒 よびサッカーで夏秋季開花が発生し, サッカーが皃とんど 発生しない 'Bluecrisp' ではシュートでの久夏秋季開花が 発生した（第 2 図，第3図）。このように, 夏秋季開花が 発生する新梢の由来は, 品種により異なることがわかっ た.

春季の開花では, 前年度に新梢先端部に形成された花芽 から $3 \sim 4 \mathrm{~cm}$ 汪どの花房軸が伸長し，そこに 10 個程度の 小花をつける（小松，2015）(第1図D）。一方，夏秋季の 開花では，春季の開花とは異なる花序の形態を示した（第 1 図 A，B，C)。一般に落葉果樹は，冬季に休眠して成長を 停止する. この時, 十分な休眠を経過しないと翌年の開花
および成長が正常に行われない（壽松木，2009)。八イブッ シュブルーベリーに扔ける低温要求時間は $800 \sim 1,060$ 時 間（Eck, 1988）で，夏秋季開花は，7月中下旬～10 月下旬 に開花するため，十分な低温に遭遇することなく，休眠を 経ず開花して抢り，このことが夏秋季開花の花序が通常 とは異なる形態を示した一因と考兄られるが，その詳細に ついては今後の形態学的調査が必要である.

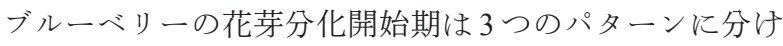
られ，ノーザンハイブッシュ種では収穫期と一致し，サ ザンハイブッシュ種では, 収穫期と一致または収穫が終了 して, 一定期間経過後, 花芽分化を開始する（Yeら, 2005)。また，ノーザンハイブッシュ種の花芽分化期間は 約 1 か月，サザンハイブッシュ種の花芽分化期間は約 1 か 月半である. 本研究の調査地である岩手県滝沢市に拈ける 'Bluetta' および゙'Patriot' の収穫期は 7 月上旬 8 月上旬 であり, 'Bluecrisp' の收穫期は 7 月下旬〜 8 月中旬であっ た.このことから，ノーザンハイブッシュ種の 'Bluetta' 拉よび 'Patriot' の花芽分化開始期間は， 7 月上旬 8 月上 旬であったことが推定できる。 また，サザンハイブッシュ 種 'Bluecrisp' の花芽分化開始期間は，早い場合で7月下 旬〜9月中旬であった可能性がある. 1 品種に抢ける春季 開花の期間は通常 3 週間程度であるが，夏秋季開花は $3 \sim$ 4 か月間継続して発生した（第 2 図，第 3 図)．春季の開花 では，前年に分化した花芽が冬季の休眠後に，適当な温度 に遭遇することで開花する，そのため，花芽分化期間が約 2 か月であっても春季の開花は, 花芽の萌芽開始期が比較 的揃う。ブルーベリーと同様に, 頂側生花芽の結果習性を 示すリンゴでは，新梢の伸長停止後に花芽が分化し始める ことから，新梢が短いもの活ど花芽分化の時期は早くな り, 栄養成長が強く, 新梢の伸長停止が遅いもの注ど花芽 分化の時期は遅くなる (阿部・荒川, 2015)。 また, 多く 

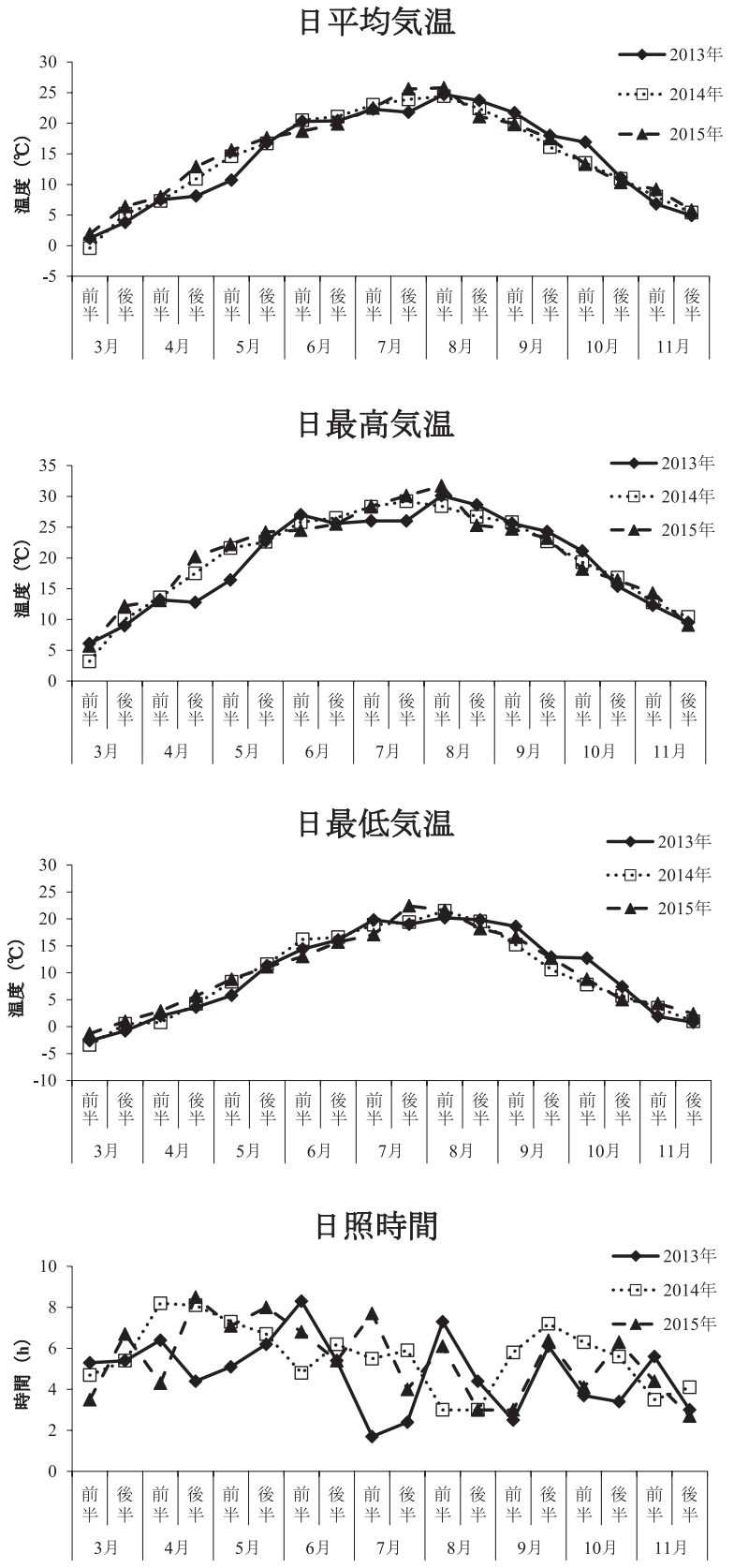

第 5 図調査期間の気温および日照時間

の果樹では, 長い新梢活ど伸長停止期が遅くなる傾向を示 す（高橋, 1998). 夏秋季開花したシュートおよびサッカー は通常の新梢と比較して長く，約 $70 \sim 100 \mathrm{~cm}$ (第 4 表) であったままた，新梢長のばらつきが大きいことから，各 新梢の長さにより停止時期が異なり, 花芽分化時期も大き く異なった可能性がある.さらに分化した花芽は休眠を経 ずに当年に開花するため，開花期間が $3 \sim 4$ か月にもなっ たと推察される.

本研究では，2014年打よび 2015 年と比較して，2013 年 の夏秋季開花の発生数が多かった (第 3 表). 夏秋季開花 は不時開花であるため, その発生には気象要因が関与して いると考兄られる。調査した 3 年間の気象条件を比較する
と, 2013 年は 2014 年, 2015 年よりも，7月の日最高気温 が低く，日照時間が少なかったことに加光，9月，10月の 温度が高めに推移した（第 5 図）。このことから，夏秋季 開花の発生は，7月の日中の気温がやや低いこと拈よび寡 日照と 9 月，10月の高温により促進されることが示唆され た。サザンハイブッシュ種は，16時間日長では栄養成長 を，8時間日長では花芽分化を盛んに行い（Spannら， 2003)，2 $1^{\circ} \mathrm{C}, 8$ 時間日長の際に花芽分化が増加する (Spann ら，2004）。また，周ら（2011）は，ハーフハイハイブッ シュ種扐よびノーザンハイブッシュ種を5，6月に，サザン 八イブッシュ種を 6,7 月に高冷地に山上げすることで, 花芽着生数が増加することを報告している. このよらに, 八イブッシュブルーベリーは，低温・短日条件で花芽分化 が促進される。また，リンゴでは，強い光は伸長を抑制 し，かるく日覆いすることで，新梢の生育がよくなる（横 田，1982）。2013 年 7 月の日照時間は 64.2 時間で，日射量 は $11.7 \mathrm{MJ} ・ \mathrm{~m}^{-2}$ であった一方， 2014 年の日照時間は 176.8 時間で，日射量は $18.2 \mathrm{MJ} ・ \mathrm{~m}^{-2}$ であった，このように， 日照時間の少ない年は，曇天で日射の弱い日が多い傾向が ある。従って，2013 年は花芽分化と新梢の生育が促進さ れやすい気象条件であったと考兄られる。また，2013年 11 月下旬の新梢先端部では, 夏秋季開花直前で生育が停 止したような状態が多数見られた。これは，9月，10月の 高温により，新梢の生育が促進されたが，その後，気温の 低下により，生育が停止したものと考光られる。このこと からも，秋季の高温は夏秋季開花に促進的に働くことが推 定された。

本研究では，ハイブッシュブルーベリーに抢ける夏秋季 開花の花序の形態, 発生時期およびその程度を明らかにす ることができた．しかしながら，夏秋季開花の様式は，春 季開花とは異なるため，夏秋季開花の花芽分化条件も春季 開花とは異なる可能性がある。 また，なぜ伸長旺盛な新梢 上で夏秋季開花するのかその原因は不明である。ささらに， 新梢は花芽分化後に自発休眠に入るため，夏秋季開花には 自発休眠の導入時期も影響すると考兄られる. 今後, 夏秋 季開花の発生機構について，さらなる調査が必要である.

\section{摘 要}

ハイブッシュブルーベリーの夏秋季開花を夏秋季採り もしくは二季採りに応用することを目的とし，八イブッ シュブルーベリー 78 品種について, 夏秋季開花の発生時 期扔よびその程度を調查した。.'Bluetta'，'Puru' 抒よび 'Bluecrisp' では調査期間内の発生数が多かったことから, 夏秋季開花しやすい品種と考光られた。 れた，7月中下 旬 11 月上中旬に夏秋季開花が見られ，70 100 cm 程 度の新梢の先端で開花した. 'Bluetta', 'Patriot'抽よび 'Spartan' ではシュート抒よびサッカーで，'Bluecrisp' で はシュートの久で夏秋季開花が発生した，夏秋季に開花し た花序は，春季開花とは異なり，花房を形成せず，当年に 
伸長した新梢の先端部の各葉腋に 1 つずつ小花をつけた. また，新梢当たりの小花数は3.9〜 4.8 個であった. 2014 年打よび2015年と比較して, 夏秋季開花の発生数が多かっ た 2013 年の 7 月は, 日中の気温がやや低く, 寡日照であ り，9，10月は高温であったことから，夏秋季開花の発生 と気象条件の関連が示唆された。

\section{引用文献}

阿部和幸・荒川 修. 2015. 第3 章 リンゴ. p. 76. 金浜 耕基編著. 果樹園芸学. 文永堂. 東京.

Eck, P. 1988. Four plant development. p. 44. Blueberry Science. Rutgers University Press. London.

堀内直美 - 車 敬愛 - 星野裕昭 - 荻原 勲. 2013. 休眠前 の高温・長日処理がブルーベリー3 種の形態および生 態に及ぼす影響. 園学雑. 12: 281-288.

小松春喜. 2015. 第 8 章 特産果樹. p. 240. 金浜耕基編. 果樹園芸学. 文永堂. 東京.

黒田治之. 2002. VI成長, 開花と結実. p. 140. 間苧谷 徹編著. 新編果樹園芸学. 化学工業日報社. 東京.

丸尾勇治郎・山下泰生・大谷啓三. 1999. ブドウ ‘藤稔” の二期作栽培に関する研究. 香川農試研報. 51: 5159.

荻原 勲. 2013. 施設果樹のこれからを考える. p. 46-51. 果実日本. 日本園芸農業協同組合連合会. 東京.

Spann, T. M., J. G. Williamson and R. L. Darnell. 2003. Photoperiodic effects on vegetative and reproductive growth of Vaccinium darrowi and V. corymbosum interspecific hybrids. HortScience 38: 192-195.

Spann, T. M., J. G. Williamson and R. L. Darnell. 2004.
Photoperiod and temperature effects on growth and carbohydrate shortage in southern highbush blueberry interspecific hybrids. J. Amer. Soc. Hort. Sci. 129: 294-298.

壽松木 章. 2009. 第 6 章 園芸作物の発育に伴ら生理生 態的特性と栽培管理. p. 131. 金浜耕基編著. 園芸学. 文永堂. 東京.

高橋国昭. 1998. 第 1 章 果樹の物質生産と栽培技術. p. 45-107. 高橋国昭編著. 物質生産理論による落葉果 樹の高生産技術. 農文協. 東京.

玉田孝人. 1998. ブルーベリ一生産の基礎〔19]。農業抒 よび園芸. 73: 77.

Thanda, A., Y. Muramatsu, N. Horiuchi, C. Jingal, Y. Mochizuki and I. Ogiwara. 2014. Plant growth and fruit quality of blueberry in a controlled room under artificial light. J. Japan. Soc. Hort. Sci. 83: 273-281.

Wright, G. 1993. Performance of southern highbush and rabbiteye blueberries on the Corindi Plateau N. S. W. Australia. Acta Hortic. 346: 141-148.

Ye, Y., N. Aoki, N. Konishi and N. Patel. 2005. Patterns of flower-bud differentiation, development, and growth habits of several blueberry (Vaccinium spp.) cultivar types grown in Japan and New Zealand. J. Japan. Soc. Hort. Sci. 74: $1-10$.

横田 清. 1982. IV 各生育段階とその生理. p. 54. 農業 技術大系 果樹編 1-II リンゴ. 農文協. 東京.

周 雪賓・青木宣明・東出忠桐. 2011. ブルーベリーの花 芽着生に及ぼす山上げ処理の効果および山上げ樹の促 成栽培. 農業生産技術管理学会誌. 18: 1-9. 